\title{
The Implementation of Halal Tourism Ecosystem Model in Borobudur Temple as Tourism Area
}

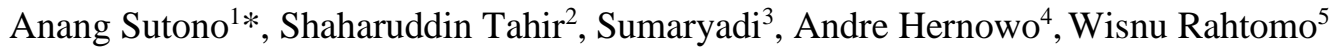 \\ ${ }^{1,3}$ Department of Tourism Business Management, Sekolah Tinggi Pariwisata NHI Bandung \\ Jl. Dr. Setiabudhi, No. 186, Hegarmanah, Cidadap, Kota Bandung, Indonesia \\ ${ }^{2}$ School of Tourism, Hospitality and Event Management, Universiti Utara Malaysia \\ College of Law, Government \& International Studies (COLGIS), Universiti Utara Malaysia, 06010 UUM, \\ Sintok, Kedah, Malaysia \\ ${ }^{4}$ Department of Hotel Administration, Sekolah Tinggi Pariwisata NHI Bandung \\ Jl. Dr. Setiabudhi, No. 186, Hegarmanah, Cidadap, Kota Bandung, Indonesia \\ ${ }^{5}$ Department of Destination Management, Sekolah Tinggi Pariwisata NHI Bandung \\ Jl. Dr. Setiabudhi, No. 186, Hegarmanah, Cidadap, Kota Bandung, Indonesia \\ e-mail: anang@stp-bandung.ac.id*1, shah299@hotmail.com ${ }^{2}$, sumaryadi@stp-bandung.ac.id ${ }^{3}$, \\ anh@stp-bandung.ac.id ${ }^{4}$, wisnurahtomo@stp-bandung.ac.id
}

* Corresponding Author

Received: January 27, 2021; Accepted: February 24, 2021

\begin{abstract}
Borobudur as one of the top wonderful destinations in the world is challenged to become one of halal tourism destinations in Indonesia. The purposes of this research are to find out and to launch the implementation of halal tourism ecosystem model in Borobudur Temple as tourism area in Indonesia. This research used a descriptive method. The researcher investigated the implementation of halal tourism ecosystem model in the Borobudur temple as tourism area by examining the variables of halal tourism ecosystems. It consisted of four dimensions. They are destination products, government support, human resources, and infrastructure. The main data is collected by using interviews and addressing of Borobudur Temple Tourism Park management, Tourism Business People that concerned with halal certification, LPPT (Integrated Research and Testing Laboratory) University of Gajah Mada, Indonesian Ulama chapter Jogjakarta, Culture and Tourism Region of Jogjakarta. The tools of data collection are the checklist and literature study to grab the secondary data. The result shows that Halal Tourism destination product, including the availability of halal attraction, facility, accessibility, program, and the package are not available completely. However, the support aspect from the government is not optimal in supporting Borobudur as halal tourism destination. Based on human resources aspect, there is founded that in some aspects such as the availability of human resources that understand of tourism is very poor or almost none. Besides, based on infrastructure aspect, there is founded that research and development aspects have not been carried out optimally.
\end{abstract}

Keywords: halal tourism, halal tourism destination ecosystem, halal tourism model.

\section{Introduction}

Indonesia is a country with a Muslim majority population. Data from the Ministry of Tourism in 2015 stated that more than 220 million Muslim tourists travel with a turnover of more than 770 trillion. The Crescent rating Comcec Report on February 2016 stated that the turnover of global Halal tourism would reach more than two trillion USD that has growth of 9\% in 2020.

Seeing the booming trend in the global halal tourism market, countries with Muslim majority populations, such as Malaysia, Turkey, the United Arab Emirates, Saudi Arabia, Pakistan, and others, even non-Muslim countries such as Thailand, Singapore, Japan, Korea, have developed the tourism seriously to reach Muslim market. Based on the rank of GMT140 for the Top Ten Halal Friendly Holiday Destinations in 2015 showed that Indonesia was at 4th and 70.6 (up 2 ranks from 2014) of the index.

In early 2016, the Government of Indonesia through the Ministry of Tourism established a team for accelerating Halal tourism development. Halal tourism was targeted to contribute 5 million inbound tourists from the total of 20 million in 2019 as the first rank in the Global Muslim Travel Index (GMTI). Halal tourism development was used as an effort to differentiate products and tourism markets.

The definition of halal was defined as "something permissible, concerning of freedom and carried out by God's law", (Al-Qaradhawi, 2013; p. XXV). The term of Halal means 'allowed' according to Islamic teachings (Sharia law). Halal is also one of the five actions (al-hakim al-kasha) 
which are categorized as the morality of human actions in Islam, namely Ford (obligatory), mustahabb (recommended), Makruh (disliked), and Haram (prohibited) (Faruki, 1966). From Islamic perspective, Based on the previous definition of Halal was referred to the practices or the activities in tourism that were 'allowed' according to Islamic teachings.

Halal tourism is a set of extended services of amenities, attractions, and accessibilities that aim to deliver and also fulfil Muslim travellleer's experiences, needs, and wants (Sutono, 2019). If the definition of Tourism above is combined with the notion of Halal, it will be defined as "Various kinds of tourism activities and supporting facilities and services that were allowed in as Muslim tourists needs that was provided by local communities, fellow tourists, government, local governments, and entrepreneurs". There were 11 criteria based on Global Muslim Travel Index (GMTI) as follows: 1) Muslim Friendly Destination; 2) Muslim Travellers \& General Safety; 3) Muslim visitor arrivals; 4) Dining options and Halal Assurance; 5) Access of Prayers places; 6) Accommodation Options; 7) Airport Facilities; 8) Muslim Traveller Needs Awareness \& Outreach; 9) Easy of Communication; 10) Air Connectivity, and 11) Visa Requirements.

The ecosystem approach of Halal Tourism destinations standard is needed for seeing halal tourism destinations as an environment that has various elements contributions in sussing tourism destinations. The perspective of Halal Tourism destinations is illustrated in the Tourism Destination Ecosystem concept. Halal Tourism Destinations can be interpreted as the destination that serves/meets the needs of Muslim tourists. For achieving them, four aspects will affect the environment of halal tourism destinations to provide good services for Muslim tourists.

The tourism destination products are the conditions of an available tourism product at the tourism destination which have four components of the forming destination products, namely physical products, programs, tour packages, and humans (Morrison, 2013). In the process of managing a product, the destination is required to develop the product that can hit the market needs where the ability to realize compatibility between products and markets will become the key success factor for managing destinations. Knowledge of market profiles and preferences are very important in designing products.

In early 2016, Indonesian Government through the Ministry of Tourism had established the team for accelerating halal tourism development. Halal tourism was targeted to contribute 5 million inbound tourists from the total of 20 million in 2019 as the first rank in the GMTI. Halal tourism development was used as an effort to differentiate products and the tourism market. The government supported the Borobudur region as one of the top ten national destinations.

In supporting the development of halal tourism, the central and regional government had issued many regulations that support sharia tourism. For example, the Government has issued a Sharia Hotel Management Act and a Halal Product Guarantee Law. Some regional governments had also issued local regulations on halal certification, namely the Jakarta Governor Regulation No. 158 of 2013 concerning halal certification, and also the West Java Regional Regulation No. 13 of 2015 concerning Supervision of Halal Products and several other regional regulations. These indicate that the central and regional governments were actually very supporting the halal tourism programs, and then the community and business actors showed how they actualized the program. Meanwhile, fostering halal awareness is important in influencing Muslim purchasing decisions to choose halal-certified products and how to recognize the characteristics of products that have been certified (Sestina \& Redland, 2020).

The support of the human resources existence for halal tourism industry is very important. As the result, the workers as operators, supervisors, executives are needed. Besides, the availability of the capable and knowledgeable auditors of halal tourism products and industries are also important for halal tourism. Human resources and the leaders who have experienced and attended in handling halal sspecial training product and familiar with halal tourism issue are needed. Hopefully, being the institutions of halal tourism areas can take their responsible of their roles.

The physical and social infrastructures are the basic physical needs of organizing structural systems needed for economic guarantees in public and private sector. Based on the Law No. 10 of 2009 about the tourism in Indonesia and then clarification with "the greatest concept" in Indonesian Tourism Marketing, 'The Greatest Concept' is a tourism regional development approach that is integrated with infrastructure, accessibility, connectivity, activity, facility, hospitality, and market preferences dimensions are related to the entrance or the distribution point, tourist movement patterns, business readiness, certainty, and tourism management procedures in improving the positive impact of the optimization value on the community, business, and region. 
Knowing that the countries which have high Muslim population such as Malaysia and Indonesia, enjoy greater preference as destinations selected for Halal tourism by Muslims all over the world. Obviously, the Muslims' insight can be felt more comfortable in the environment such as following Islamic law in diet, attire, and other customs. While, it may not be easy for the minority of Muslim population countries to ensure such as the compliance on Muslim guests. It can be achieved when the systems exercise tolerance of the difference. Turkey has emerged as the growing destination for Halal tourism, which not only attributed on Islamic heritage, but also attributed in a formal secular State due to its historic tolerance of religious beliefs. Furthermore, both Muslim and non-Muslim tourists has alike (Mohsin et al., 2016)

Recently, halal tourism as a market segment has grown and emerged with the strength. The increase of the Muslim population worldwide is more favaurabble in economic conditions. Also, the desire to travel and to know other places are confronted with new challenges of the tourism industry. In this case, a recent study published in January of 2018 by Crescent Rating identified the following ten key halal travel trends: Halal Digital Economy, the Rise of Muslim Female Travelers, the Asian Destinations Leadership, the Development of Halal Travel Ecosystem, Halal Authentication, or Muslim-Friendly Tourist Services, the discovery content and halal experiences, the Spreading Travelers' Visual Stories, the Role of Artificial Intelligence (AI), the Brand Empathy to connect with Muslim travelers, the Sustainability and the Community Initiatives (Sanchez \& Moral, 2019).

The Borobudur Temple that designated as one of the top 10 national destinations in 2016, was one of the world tourism destinations and held one of the wonders of the world, also needed to be directed to prepare itself for the establishment of halal tourism. The productivity of Borobudur in developing halal tourism will have significant impact on the vision achievement in 2019. Because of that, there is needed the extent examination of Borobudur that related to halal tourism ecosystems.

The purpose of this research was to reveal the extent application of halal tourism in the framework of the halal tourism ecosystem model in the Borobudur Temple as tourism area with the following research objectives: 1) Disclosure of variables in halal tourism ecosystems; 2) Disclosure of the application of halal tourism; 3) An advice of the strength application opportunities of halal tourism.

\section{Materials and Methods}

The study of the implementation of halal tourism ecosystem model in the Borobudur Temple as tourism area examined the variables of halal tourism ecosystems. They are the destination products, the government support, human resources, and the infrastructure. This research identified all the conditions of halal tourism destination ecosystem in the Borobudur temple as tourism area at the right time. The study method used descriptive.

The descriptive approach was intended to find out the destination products, local government support, human resources, and infrastructure aspects around Borobudur. It aims to make the systematic, factual, and accurate description of the facts and traits, also the relationships between the phenomena investigated (Sugiono, 2009). In this study, all aspects were part of the implementation studies of halal tourism ecosystem model in the Borobudur Temple as tourism area.

The data collection techniques of this research were; 1 ). Interviews, interviews were conducted to identify the policies and the extent implementation of halal tourism in Borobudur Temple Tourism Park. The interviewees were the management of the Borobudur Temple Tourism Park, the Yogyakarta City Culture and Tourism Office, the Jogjakarta MUI, and several tourism business managers who have motivation in arranging halal certification, and Gajah Mada University Integrated Research and Testing Laboratory (LPPT). The data collection tool used was an interview guide, 2). Observation, observations were made at the Borobudur Temple Tourism Park. The data collection tool used was a checklist, 3). Literature study, the literature study was conducted to obtain secondary data related to the research topic.

\section{Result and Discussion}

Based on the capacity aspect, Borobudur temple as tourism area products as one of the national priority destinations can be developed as one of the national halal tourist destinations in reaching inbound Muslim tourism segments.

The results of the assessment of four destination product dimensions show that the Borobudur temple as tourism area has tourist attraction that related to halal tourism principle. With the support of accessibility that is already excellent and the existing conditions of numbers of inbound tourists and 
domestic tourists visit are high, the opportunity to make Borobudur as a halal tourist destination is opened widely. Based on the data, the dimensions of tourist attractions owned by the Borobudur temple area are good (4.0). It shows that Borobudur is the potential to become halal tourism destination. This achievement is supported by positive and safe image conditions, the availability of art, and cultural activities. The thing that is still an obstacle is that none of the tour guides have participated in halal tourism training. The result is in line with the statement from to Battour et al. (2017) stated that perception of halal tourism destination products and services with good accessibility has significant relationship with the quality and trip value.

In tourist facilities aspect that related to 'need to have' facilities or basic facilities for halal tourism have been fulfilled. They are the ease and availability of the signpost for mosque. The thing that needs to be improved is a mosque that separate men and women. The weakness of it is the absence of tourist facilities that have certified halal such as hotels and travel agents that provide halal tourism packages in the Borobudur region. However, the lack of halal-certified restaurants are feared to reduce the attractiveness value as halal tourist destinations.

However, it was identified that the dimensions of the programs and packages characterized by halal tourism were still constrained. Recently, there is still no halal tour packages, event and halal lifestyle festival that become the attractions for halal tourism tourists. Generally, the function of the government includes three main functions, such as the functions of regulation, service, and empowerment. Regarding to the development of halal tourism, the regulatory function of the government is needed for its implementation. It is carried out by the government by arranging the legislation to regulate human relations in society. The government is capable party of implementing regulations. Thus, the life can run well and dynamically.

To see the extent of the government's role in implementing the regulatory function, the research team highlighted three dimensions approach below:

a. Policy (regulation \& guidelines): policies (central and regional) are available to support Borobudur as halal tourism destination. There is the government policy (as the owner of Borobudur) to launch Borobudur as halal tourism destination and there is also local government policy to support Borobudur as halal tourism destination and the availability of guidelines for 'halal tourism development'.

b. Planning: the availability of the Borobudur database as halal tourism destination. Also, there is regional government strategic program to support Borobudur as halal tourism destination.

c. Development: Halal Tourism promotion, guidance and supervision in the application of Halal Tourism destinations, support of provincial and/or district/city governments for halal tourism business certification (in the form of partial subsidies or the whole costs of halal certification), support of Indonesian Ulama Council and Indonesian Assessment Institution in developing halal tourism, facilitation of halal tourism training, stakeholders support halal tourism (Islamic mass organizations, etc.).

The researchers carry out the observations in the Borobudur temple as tourism area by interviewing the management of Borobudur temple tourism park area directly. Based on the policy dimension (regulation \& guidelines), the government supports for halal tourism in Borobudur temple tourism park area is still very weak. It can be concluded that there are no specific indicators. It can be seen from the absence of the central government's instruction on policies issue to arrange Borobudur as halal tourism destination.

From the policy (regulation \& guideline) dimension and the government policy indicators (as Borobudur owners) that arrange Borobudur as halal tourism destination, even though the government support is still weak but they try to support and prove it from the local government support. From the Policy (regulation \& guideline) dimension, the local government's policy in supporting Borobudur as halal tourism destination can be seen. The government support has felt strongly by supporting Borobudur as halal tourism destination and also providing guidelines for halal tourism development. This is suitable with the statement "in a clear legal related to halal tourism and the creative economy, there is an amplifier to actually implement it without any legal irregularities. Shariah regulation that is really specifically and legally stated in the form of regulations that were formalized nationally by the government. Thus it becomes a reference for the development of tourist attractions in Indonesia" (Lestari, 2019).

In planning dimensions asppect, the government support for halal tourism in the Borobudur temple tourism area is still very weak, and it can be said that'not exist for both indicators. It can be seen from the absence of the strategic databases and programs which are not available yet. The third- 
dimension is' Development' which consists of six indicators. There are three indicators of goverrnment support that are still weak and 3 three indicators are good support.

The government support for halal tourism in the Borobudur temple as tourism area is still very weak, and it can be said that there is 'no indicators'. It can be seen from the lack of the socialization of halal tourism, guidance, supervision, and the certification have not implemented in the Borobudur area. It is considered as strong support for the 'Development dimension' from Indonesian Ulama Council support indicators in developing halal tourism; Facilitation of halal tourism training and stakeholders support for halal tourism (Islamic mass organizations, etc.). It is proven by the existence of this institution that has the authority to conduct halal certification.

The analysis of Human Resources sub-variables is described in three dimensions, namely; HR Knowledge about Halal Tourism, Management Vision of Halal Tourism', and Auditors of Halal Tourism. Human resources are the important asset for the organization in any industries including Halal tourism industry. It is mentioned and strengthen clearly by Atoyan (2015) that the role of human resources is not only to make a suitable regulation for developing Halal tourism industry but also for example providing the best services in hotel or any tourism destinations that fit the Muslim tourists. The quality of employees and effective management affect the success of the tourism and hospitality industry.

The analysis results from the HR knowledge of Halal Tourism variable are divided into two indicators as follows:

a. The availability of Tourism HR who have participated in Halal tourism/product training, the research team observed the Halal Tourism Ecosystem Model in Borobudur temple as tourism area of the availability of tourism human resources who have participated in training related to halal tourism/halal products with zero score as the indicator. It shows that human resources as intended person is not available in the Borobudur area. The unavailability of human resources who have participated in the training of halal tourism products and/or halal tourism has an implicit meaning that workers or anyone who involved in the implementation of tourism activities in Borobudur tourist which has not proper knowledge about halal tourism and other halal products.

b. Having experience in handling 'halal tourism/product', it means that the research team observed the implementation of Halal Tourism Ecosystem Model in Borobudur temple as tourism area with zero score. It shows that human resources in the Borobudur temple as tourism area did not have experience in handling halal tourism or halal tourism products. The implications of the absence of human resources who have experience in halal tourism and/or halal tourism products can 'not be good' for Muslim tourists. For example, Muslim tourists who get dissatisfaction experience after visiting Borobudur temple as tourism area in their basic daily needs as Muslim tourists is not fulfilled.

The analysis results of the Halal tourism management vision variable are divided into three indicators as follows:

a. The level of leaders' understanding of halal tourism, strategic such as determining the direction of the company's pace in developing products or determining targets market or other types of fundamental policies is some examples of responsibilities that are under the control of the company's leadership. In tourism implementation case, by tourism business, the entities cannot be separated from the company leadership policies. Of course, beside the business calculation that is capturing the Muslim travelers' niche market, there is a personal mission for the leader tourism company in implementing Islamic law. In bussiness interest aspect, the needs to grab the Muslim tourist market requires an understanding of the market characteristics. The Crescent Rating site (www.crescentrating.com) suggests that Muslim travelers at least consider four basic aspects before determining accommodation options, such as halal food, prayer facilities, Ramadan services, and non-halal activities.

b. In halal food aspect, a high rating will be given to hotels that can provide halal-certified kitchens, halal-certified restaurants, and offer halal menu. Then for getting high rating prayer facilities will be given to the hotels that can provide prayer mats, prayer schedules, Qibla direction, including the distance from the hotel to the mosque - the closer and the higher, the rating will be given. From the explanation of the example above, it is clear that making choices to accommodate Muslim tourists is the strategic role of the company's leadership. The reason is very clear because every decision such as fulfilling the needs of Muslim tourists will affect many aspects of the company's management, from work programs, budgets, the preparation of staff training related to halal tourism. 
The research team observations related to the point of the level of understanding of the leadership towards halal tourism' showed sufficient value. If it is elaborated with the strategic role that carried out by the company leadership, it will be interpreted as follows; the aspect of making important decisions related to the implementation of halal tourism ecosystems in his company and the leader is not ready. In other words, 'three points' of the indicator mean the leader is not ready to implement halal tourism policies or make his company being Muslim-friendly.

c. Policy to implement halal tourism, as a strategic decision, the policy have long-time vision, complex managerial consequences, and requires the implementation of various aspects of service from the accommodation industry. For example, starting from the front office to the back office. From the managerial level to the operational or practical level which has the role of employees in the operational field. Based on the previous point that understanding of the leadership is at a sufficient level. Then, "the existence of policy to implement halal tourism scored one. It means that the locus is observed by the research team that have the policy that is still general to implement halal tourism.

There are technical instructions that have been made related to the implementation of halal tourism. In the management hierarchy, the technical instructions are needed by those at the lowest level that called workers. The management hierarchy model of the company describes the levels, starting from the top-level, the Executive, Senior Manager, Middle Manager, and workers/Employee. While generally, it is often used in the management hierarchy consists of Upper Management that has the responsibility to determine the strategic long-term goals: products, markets, business organizing.

The analysis results of Auditor 'Halal Tourism' variable are divided into two indicators as follows:

a. The availability of 'halal tourism/product' auditors, according to the Minister of Tourism Regulation Number 1 of 2016 concerning the Implementation of Tourism Business Auditor Certification in tourism or called as Auditor is someone who audits in the tourism sector. The tourism auditor must have an Auditor Certificate issued by training institution that has been accredited by an authorized accreditation institution and appointed by the Ministry.

b. To establish the high competency standards, Indonesian Ulama Council certifies halal auditors. They have strategic and decisive position. Because the mufti in Indonesian Ulama Council commission stipulated the fatwa of halal products based on information from halal auditors who conducted inspections or halal audits in companies that submitted applications for halal certification.

The research team observation results for the implementation of Halal Tourism Ecosystems in Borobudur temple as tourism area has zero score. It means that almost all observation tourism locus halal auditor and halal product auditor are not available. This is in line with the previous observation points related to the understanding of leadership, the absence of policy to implement halal tourism, and the absence of technical guidance related to the implementation of halal tourism. The role of Indonesian Ulama Council in developing halal tourism auditors, related to the point 'the role of Indonesian Ulama Council in developing halal tourism auditors' the research team gave the maximum score of five. This is related to the role of the Indonesian Ulama Council which has done many things related to the implementation of halal tourism in the special region of Yogyakarta and Central Java.

By following four elements of halal tourism ecosystem mentioned earlier, and by the concept of halal tourism globally where halal tourism provides the pleasure and convenience and also the safety in traveiling. One of four elements is Halal tourism infrastructure. The tourism sector is largely determined by the ease of mobility and infrastructure.

Supporting infrastructure in the tourist area of Borobudur temple can be elaborated based on the following elements:

a. Research and Development for the halal destination. The central government support in research and development in the Borobudur area have been carried out by Halal Research Group under the Integrated Research and Testing Laboratory of Gajah Mada University (UGM) where halal tourism has potential aspects to be developed because the market is very potential.

b. Traceability system. There is no available information system for halal tourism destinations traced, as well as the unavailability media kits about halal tourism destinations. The government agencies, in this case, the provincial and city tourism service said that there were no traceable information system and Halal tourism destination kit for the Borobudur area and also the information obtained from Borobudur managers. 
c. Halal Standard \& certification. The availability of halal tourism standards, halal tourism business certificate types, and halal tourism certification are important. Indonesian Ulama Council as the government agencies have certified food and beverage business and accommodation but there is no non-governmental institution that has made Halal certification for the area. It is also the connection with the statement "as the Muslim consumers become more knowledgeable of their religion, it is inevitable that they will be more particular of products type and services that they consume or use" (Othman, 2006).

Generally, although there is no policy for implementing halal tourism in Borobudur temple as tourism area, it has many potential aspects to be developed. It seems that the harmony between actual conditions and the halal tourism ecosystem still have thigh gap. However, this condition is understood considering the socialization of halal tourism issue in Indonesia. It is still limited and the management still does not take halal tourism as one of the considerations in Borobudur tourism development. However, some discories showed that halal tourism in Borobudur temples as tourism area has potential aspects to be applied.

a. Potential aspects of Borobudur temple tourism products are already in line with the criteria of halal tourism, especially in tourist attractions aspect as the main factor forming tourism products. Likewise, in terms of accessibility, it has supported optimally. Travelers are very easy to reach the location. Also there are no things that can disrupt the perception of Borobudur as halal tourism destination.

b. The aspect of government support is good. The government through the tourism ministry has determined halal tourism as one of the national superior products. The supporting things include the establishment of the National Halal Tourism Development Acceleration Team. The membership is 'Penta helix', the criteria for developing halal tourism has been structured. Also, the hard work to implement the development is synergy. Regarding the efforts to foster synergy, the strong collaboration with regional leaders, the council of ulama institutions were established as an institution authorized to conduct halal certification, up to universities and communities. If those capacities have been implemented properly then it is believed to provide the strong boost for the implementation of halal tourism in the Borobudur temple as tourism area. Moreover, Borobudur temple as tourism area is owned and managed by the government. Furthermore, if there is an important decision to be implemented about halal tourism in Borobudur, it will have very positive effect.

c. On the other hand, some deficiencies or limitations were identified that could hinder the implementation of halal tourism. Human resources support and halal tourism infrastructure are still weak. In the context of governance, limitations on human resources aspects and systems have strong influence which has less productive on development efforts. By identifying each subsystem condition of halal tourism ecosystem in Borobudur, through in-depth study, the grand strategy can be developed for the application of halal tourism in Borobudur temple as tourism area.

\section{Conclusion}

The summary can be stated as follows: halal tourism destination product which included availability of halal attraction, facility, accessibility, program, and the package are not fully available. For example, there are still no halal tour packages, events, or halal lifestyle festivals. The policy (regulation \& guideline) dimension of government support for halal tourism in Borobudur Temple as tourism area are not optimal. There is no halal policy, regulation, guideline, planning, and development. The infrastructure availability of research and development, traceability system, halal standard certification, and halal training, are not carried out. In human capital aspect, the availability of halal tourism human resources who have participated in halal tourism product and training, experienced in handling halal tourism product, and halal tourism auditors are very limited. On the other hand, the recommendations that can be taken into account are the needs for training of halal tourism to local guides to improve the quality of service for Muslim tourists. By improving the quality of tourist facilities, from the 'need to have' to be 'good/nice to have' by paying many attentions to the need for separation facilities between men and women. It is needed to begin the compilation of Borobudur halal tour packages, events, and halal lifestyle festivals which can become more attractive for tourists of halal tourism, the need for the strategic program of the regional government to support Borobudur by providing training, tourism activities, seminars on Halal Tourism, guidance, and supervision to the application of halal tourism destinations, and support from provincial and/or district 
government for halal tourism business certification. The management of the Borobudur temple tourism area can arrange the elaboration and cooperation with the government in implementing the development of Halal Tourism. By socializing which is integrated with human resources who join the training in Halal tourism services and offers Halal products, 4). the Indonesian Ulama Council and Ulama Council of Yogyakarta need to develop halal tourism auditors, including product certification and halal tourism auditors by implementing comprehensive training for broading the knowledge about the importance of halal products and services.

\section{References}

Lestari \& Amsari. (2019). The Communication of Halal Tourism with Sharia Regulation In Increasing Income and Community Welfare In North Sumatra. In Proceeding International Seminar on Islamic Studies, 1(1), $453-464$.

Mohsin, A., Ramli, N., \& Alkhulayfi, B. A. (2016). Halal tourism: Emerging opportunities Tourism Management Perspectives, 19, 137-143.

Morrison, A. M. (2013). Hospitality and Travel Marketing Edisi Ketiga. USA: Delmar Thomson Learning.

Palupi, M., Romadhon, R., \& Arifan, N. (2017). The Importance of Optimization of Halal Tourism: A Study of development of Halal Tourism in Indonesia. In Conference: 29th International Business Information Management Association (IBIMA).

Peraturan Gubernur Provinsi Daerah Khusus Ibukota Jakarta Nomor 158 Tahun 2013. Tata Cara Sertifikasi Halal Restoran dan Non Restoran. 19 Desember 2013. Berita Daerah Provinsi Daerah Khusus Ibukota Jakarta Tahun 2013 Nomor 65023. Jakarta.

Peraturan Menteri Pariwisata dan Ekonomi Kreatif Republik Indonesia Nomor 2 Tahun 2014. Pedoman Penyelenggaraan Usaha Hotel Syariah. 9 Januari 2014. Berita Negara Republik Indonesia Tahun 2014 Nomor 74. Jakarta.

Rahman, M., Moghavvemi, S., Thirumoorthi, T., \& Rahman, M. K. (2020). The impact of tourists' perceptions on halal tourism destination: a structural model analysis. Tourism Review, 75(3), 575-594.

Sánchez, A. \& Moral-Moral, M. (2019). Halal tourism: state of the art. Tourism Review, 74(3), 385399.

Septiani \& Ridlwan. (2020). The Effects of Halal Certification and Halal Awareness on Purchase Intention of Halal Food Products in Indonesia. Indonesian Journal of Halal Research, 2(2), 5560 .

Sutono, A. (2019). Buku Rencana Strategis Pengembangan Pariwisata Halal. Bandung.

Undang-Undang Republik Indonesia Nomor 10 Tahun 2009. Kepariwisataan. 16 Januari 2009. Lembaran Negara Republik Indonesia Tahun 2009 Nomor 11. Jakarta.

Undang-Undang Republik Indonesia Nomor 21 Tahun 2008. Perbankan Syariah. 16 Juli 2008. Lembaran Negara Republik Indonesia Tahun 2008 Nomor 94. Jakarta.

Undang-Undang Republik Indonesia Nomor 33 Tahun 2014. Jaminan Produk Halal. 17 Oktober 2014. Lembaran Negara Republik Indonesia Nomor 5604. Jakarta.

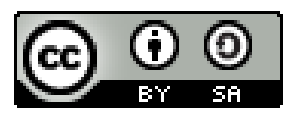

(C) 2021 by Indonesian Journal of Halal Research (IJHAR). Submitted for possible open access publication under the terms and conditions of the Creative Commons Attribution (CC BY SA) license (https://creativecommons.org/licenses/by-sa/4.0/). 